\title{
THE ANTIMICROBIAL ACTION OF DECAMETHOXINUM SUBSTANCE AT DIFFERENT PH VALUES
}

\author{
N.M.Derkach, Z.S.Suvorova \\ National University of Pharmacy \\ SI "Institute of Pharmacology and Toxicology of the Academy of Medical Sciences of Ukraine" \\ Key words: decamethoxinum; "Decasan"; antimicrobial action; antifungal action; $p H$
}

\begin{abstract}
This study considers the effect of $\mathrm{pH}$ on the specific activity of decamethoxinum substance under experimental conditions. It has been shown that the minimum inhibitory concentration (MIC) of this substance depends on the microorganism species and $\mathrm{pH}$; the lowest MIC values for S. aureus, $P$. aeruginosa, E. coli are determined in the basic medium. The significant antimicrobial activity in both acidic and basic media was shown against $S$. paratyphi, and the antifungal effect against $C$. albicans increased in the basic medium. It has been determined that decamethoxinum inhibits formation of biofilms by $E$. coli and $P$. aeruginosa, the effect depends on the concentration and $\mathrm{pH}$ (the maximal inhibitory effect is at $\mathrm{pH} 8.0 \pm 0.1$ in the concentration of 10.0). Decamethoxinum-induced inhibition of the microorganism biomass accumulation is also $\mathrm{pH}$-dependent. Thus, inhibition of the growth and reproduction of $P$. aeruginosa was observed in 6 hours of incubation with the substance at $\mathrm{pH}$ $6.3 \pm 0.4$; inhibition of the vital activity of $E$. coli was registered in the basic medium $(p H 8.0 \pm 0.1)$ in

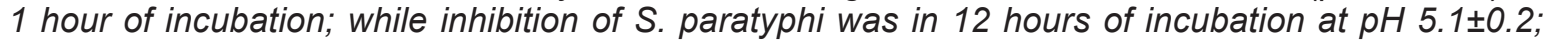
$6.3 \pm 0.4 ; 8.0 \pm 0.1$. The most significant activity of decamethoxinum against the gram-positive bacteria (S. aureus) was revealed in 6 hours of incubation at $\mathrm{pH} 5.1 \pm 0.2$. In the acidic medium mentioned the antifungal action against C. albicans was also observed with inhibition of the cell accumulation in 12 hours after the substance introduction.
\end{abstract}

Intestinal diseases of the microbial ethiology remain a global problem today because of high prevalence and a severe course, especially at a young age, in immunocompromised persons and patients with chronic pathologic processes in the gastrointestinal system. Development of resistance of infectious agents determines a need in broadening the spectrum of antimicrobial agents [9, 12]. Since biological films cause about $65-80 \%$ of all chronic infectious diseases, including the diseases of the gastrointestinal system [13], the effect of antibacterial agents on the biofilm formation and viability is especially important. In addition, the $\mathrm{pH}$ of the biological medium can determine the antimicrobial activity of substances and should be taken into account during the drug development.

To use the known antimicrobial drug decamethoxinum was recognized to be expedient for developing peroral medicinal forms for the treatment of acute intestinal diseases of the microbial ethiology. Being a surface-active cationic detergent, decamethoxinum exhibits the antibacterial, antiviral, antifungal activity of a broad spectrum; it is practically not adsorbed from the gastrointestinal tract, and can break microbial toxins and inhibit inflammation $[2,4,7]$. "Decasan" is $0.02 \%$ decamethoxinum solution for peroral use developed by "Yuria Pharm" (Kyiv, Ukraine); it is widely prescribed in infectious diseases in surgery, dentistry, gynaecology, urology, otolaryngology, pulmonology $[2,7]$. The pharmacological studies of the drug activity in the intestinal infections, as well as its toxicological properties have recently started and shown the promising results $[3,8]$.
The aim of the study is to determine the effect of $\mathrm{pH}$ on the specific activity of decamethoxinum substance, including its ability to inhibit the biofilm formation.

\section{Materials and Methods}

The experiments were conducted at the Department of Antimicrobial Agents of the SI "Institute of Pharmacology and Toxicology of the Academy of Medical Sciences of Ukraine". Decamethoxinum substance ("Yuria Pharm," Kyiv, Ukraine) was studied after its dissolution in distilled water. Clinical test strains of bacteria and fungi with different sensitivity to the antibacterial agents were used, namely Escherichia coli 1512, Salmonella paratyphi B 252, Pseudomonas aeruginosa 2094, Staphylococcus aureus 042012, as well as Candida albicans 1486. Such growth media as Müller-Hinton agar, meat peptone agar, growth media No.8, Sabouraud medium (fluid and solid) were used depending on the species, in accordance with the current recommendations $[6,11]$. Different $\mathrm{pH}$ values were used: $8.0 \pm 0.1$ (basic); $7.15 \pm 0.2$ (neutral); $6.3 \pm 0.4$ (weakly acidic), $5.1 \pm 0.2$ and $4.1 \pm 0.3$ (acidic).

The minimum inhibitory concentration (MIC) of the substance under study was determined by serial dilution in the liquid nutrient medium according to $[1,5,6]$. MIC was determined as the maximum dilution of the substance, in which there was no growth of microorganisms visually observed within the specified time (concentrations used in this study were within the range of $50.0-0.312 \mathrm{mcg} / \mathrm{ml}$ ). The density of the bacterial inoculum was $10^{5}$ colony forming units (CFU) per $1.0 \mathrm{ml}$ of medium, for yeasts this value equalled $10^{5}$ fungal elements per $1.0 \mathrm{ml}$. Bacteria 
The antibacterial activity of decamethoxinum substance

\begin{tabular}{|c|c|c|c|c|}
\hline Microorganisms & \multicolumn{4}{|c|}{ Minimum inhibitory concentration, $\mathrm{mcg} / \mathrm{ml}$} \\
\hline \multicolumn{5}{|c|}{ Gram-positive bacteria } \\
\hline \multirow{2}{*}{ S. aureus 042012} & $\mathrm{pH} 5.1 \pm 0.2$ & $\mathrm{pH} 6.3 \pm 0.4$ & $\mathrm{pH} 7.15 \pm 0.2$ & $\mathrm{pH} 8.0 \pm 0.1$ \\
\hline & 1.25 & 1.25 & 0.62 & 0.62 \\
\hline \multicolumn{5}{|c|}{ Gram-negative bacteria } \\
\hline E. coli 1512 & 12.5 & 6.25 & 6.25 & 3.12 \\
\hline S. paratyphi B 252 & 0.62 & 1.25 & 1.25 & 0.62 \\
\hline P. aeruginosa 2094 & 50.0 & 50.0 & 50.0 & 25.0 \\
\hline
\end{tabular}

were cultivated for 24-48 hours (depending on the species) under aerobic conditions at $35-37^{\circ} \mathrm{C}$. Fungi were cultivated using Sabouraud medium for the same period at $30-35^{\circ} \mathrm{C}$. The density of the bacterial inoculum was measured using a KFK-2 photocolorimeter at $590 \mathrm{~nm}$ (bacteria) and $540 \mathrm{~nm}$ (fungi), it was equalled to $5 \times 10^{8} \mathrm{CFU} / \mathrm{ml}$ for bacteria and $1 \times 10^{6}-5 \times 10^{6}$ for fungi.

The sensitivity of microorganisms to the action of decamethoxinum was studied by the agar diffusion assay measuring the diameters of zones of the microorganism growth inhibition [1]. The concentration of decamethoxinum in the solutions was equalled to $100.0 ; 50.0 ; 25.0$; $10.0 \mathrm{mcg} / \mathrm{ml}$.

The intensity of biofilm formation [10] and accumulation of the microbial biomass in the presence of decamethoxinum at the different $\mathrm{pH}$ levels were registered using an "Absorbance Microplate Reader ELx800" microbiological analyser (BioTek, USA). The optical density was registered at $405 \mathrm{~nm}$ (samples) and $630 \mathrm{~nm}$ (reference).

Biofilms of the gram-negative bacteria $P$. aeruginosa and $E$. coli (24-h cultures) were studied. Decamethoxinum (in the concentrations equalled 10.0 MIC and 1.0 MIC in accordance with the species) and inocula of microorganisms $\left(10^{7} \mathrm{CFU} / \mathrm{ml}\right)$ were added to the growth media simultaneously. In 24 hours of incubation at $37^{\circ} \mathrm{C}$ the test objects were treated with $0.1 \%$ solution of gentian violet, washed with distilled water, the dye was extracted with ethanol.

The process of the microbial biomass accumulation was studied in the liquid nutrient media using 24-h cultures of E. coli 1512, S. paratyphi B 252, S. aureus 042012 , P. aeruginosa 2094, C. albicans 1486 (the inoculation dose was equalled to $10^{6}$ colony forming units per $1.0 \mathrm{ml}$ for bacteria and $10^{5}$ fungal elements per $1.0 \mathrm{ml}$ for fungi). After adding decamethoxinum in the concentrations mentioned above the plates were kept in a PST-60HL-4 termoshaker (Biosan, Latvia) at $37^{\circ} \mathrm{C}$ with mixing (500 rpm) for 48 hours. The optical density was registered in 1, $6,12,24,48$ hours as mentioned above. The individual control data for the growth medium sterility, as well as the culture growth were provided for each $\mathrm{pH}$ value.

The data were processed using the Microsoft Excel standard software; Student's t-test was applied. The level of significance was taken as $\mathrm{p} \leq 0.05$.

\section{Results and Discussion}

1. The minimum inhibitory concentrations of decamethoxinum substance at different $\mathrm{pH}$ values

The strains of bacteria and fungi tested were characterized by different sensitivity to antimicrobial agents. E. coli 1512 was sensitive to aminoglycosides, fluoroquinolones, cephalosporins (cephtriaxone), carbapenems, co-trimoxazole and chloramphenicol; moderately sensitive to tetracycline; resistant to ampicillin and cephepime. $P$. aeruginosa 2094 was sensitive to aminoglycosides, fluoroquinolones, carbapenems, monobactams and cotrimoxazole; moderately sensitive to cephalosporins (cephthasidime, cephtriaxone); resistant to cephepime, ampicillin and tetracycline. S. aureus 042012 was sensitive to aminoglycosides, fluoroquinolones, carbapenems, monobactams, lincosamides, cephalosporins (cephthasidime) and chloramphenicol; S. paratyphi B 252 - to all agents used (namely gentamycin, imipinem, tobramycin, ciprofloxacin, cephtriaxone). C. albicans 1486 was sensitive to azoles; moderately sensitive to amphotericin B and terbinafin.

As the data in Tab. 1 indicate, changes in the $\mathrm{pH}$ of the media affected the sensitivity of the test strains to decamethoxinum substance. Thus, the inhibitory action against gram-positive bacteria such as $S$. aureus increased in the basic medium. In relation to the gram-negative bacteria the most significant inhibition of $E$. coli was observed at $\mathrm{pH} 8.0 \pm 0.1$ with reduction of the activity in more acidic medium; S. paratyphi was sensitive to the substance effect in the basic and acidic media, while at the levels of $\mathrm{pH}$ close to the neutral one the sensitivity was slightly decreased. P. aeruginosa appeared to be less sensitive to decamethoxinum with the less evident effect in the acidic medium. The activity of the substance studied against yeasts (C. albicans) increased with the increase of the $\mathrm{pH}$ values and was equalled to $25.0 \mathrm{mcg} / \mathrm{ml}$ at $\mathrm{pH} 4.1 \pm 0.3 ; 6.25 \mathrm{mcg} / \mathrm{ml}$ at $\mathrm{pH} 5.1 \pm 0.2$; pH $6.3 \pm 0.4 ;$ pH 7.15 \pm 0.2 .

\section{Sensitivity of microorganisms to the decame-} thoxinum action in the agar diffusion assay at different pH values

As seen from Tab. 2, the inhibitory effect of decamethoxinum substance against gram-positive bacteria (S. aureus) increased in the basic medium. The same phe- 
Diameters of the zones of the microorganism growth inhibition in the presence of decamethoxinum substance at different $\mathrm{pH}$ values, $(\mathrm{M} \pm \mathrm{m})$

\begin{tabular}{|c|c|c|c|c|c|}
\hline \multirow{2}{*}{ Microorganisms } & \multirow{2}{*}{ Concentrations } & \multicolumn{4}{|c|}{ Zone of the growth inhibition $(\mathrm{d}, \mathrm{mm}$ ) } \\
\hline & & $\mathrm{pH} 8.0 \pm 0.1$ & $\mathrm{pH} 7.15 \pm 0.2$ & $\mathrm{pH} 6.3 \pm 0.4$ & $\mathrm{pH} 5.1 \pm 0.2$ \\
\hline \multirow{4}{*}{ E. coli 1512} & $100.0 \mathrm{mcg}$ & $24.2 \pm 1.08$ & $23.8 \pm 2.58$ & $21.2 \pm 0.08$ & $22.3 \pm 0.25$ \\
\hline & $50.0 \mathrm{mcg}$ & $22.7 \pm 0.33$ & $22.2 \pm 1.08$ & $18.7 \pm 0.08$ & $20.0 \pm 0.08$ \\
\hline & $25.0 \mathrm{mcg}$ & $20.7 \pm 0.33$ & $19.7 \pm 0.08$ & $17.2 \pm 0.08$ & $17.5 \pm 0.05$ \\
\hline & $10.0 \mathrm{mcg}$ & $18.5 \pm 0.05$ & $17.2 \pm 0.08$ & $13.3 \pm 0.33$ & $13.7 \pm 0.25$ \\
\hline \multirow{4}{*}{ P. aeruginosa 2094} & $100.0 \mathrm{mcg}$ & $24.8 \pm 0.08$ & $20.3 \pm 0.33$ & $11.7 \pm 0.33$ & - \\
\hline & $50.0 \mathrm{mcg}$ & $21.5 \pm 0.25$ & $17.8 \pm 0.08$ & - & - \\
\hline & $25.0 \mathrm{mcg}$ & $18.7 \pm 0.08$ & $14.7 \pm 0.58$ & - & - \\
\hline & $10.0 \mathrm{mcg}$ & $14.0 \pm 3.0$ & - & - & - \\
\hline \multirow{4}{*}{ S. aureus 042012} & $100.0 \mathrm{mcg}$ & $29.8 \pm 1.12$ & $30.2 \pm 0.08$ & $29.2 \pm 1.08$ & $30.5 \pm 0.25$ \\
\hline & $50.0 \mathrm{mcg}$ & $29.3 \pm 1.12$ & $29.0 \pm 1.75$ & $27.8 \pm 0.08$ & $28.5 \pm 0.25$ \\
\hline & $25.0 \mathrm{mcg}$ & $28.0 \pm 0.5$ & $27.5 \pm 0.75$ & $26.0 \pm 0.05$ & $26.3 \pm 0.58$ \\
\hline & $10.0 \mathrm{mcg}$ & $26.0 \pm 0.5$ & $25.2 \pm 0.58$ & $24.0 \pm 0.25$ & $23.6 \pm 0.58$ \\
\hline \multirow{4}{*}{ S. paratyphi B 252} & $100.0 \mathrm{mcg}$ & $29.2 \pm 0.08$ & $28.7 \pm 0.58$ & $27.7 \pm 0.58$ & $32.8 \pm 0.58$ \\
\hline & $50.0 \mathrm{mcg}$ & $27.0 \pm 0.05$ & $26.7 \pm 1.33$ & $26.2 \pm 0.58$ & $30.3 \pm 0.58$ \\
\hline & $25.0 \mathrm{mcg}$ & $25.3 \pm 0.33$ & $24.5 \pm 0.75$ & $24.5 \pm 0.25$ & $28.0 \pm 0.25$ \\
\hline & $10.0 \mathrm{mcg}$ & $23.8 \pm 0.08$ & $22.8 \pm 0.58$ & $22.3 \pm 0.08$ & $25.5 \pm 0.08$ \\
\hline & & $\mathrm{pH} 7.15 \pm 0.2$ & $\mathrm{pH} 6.3 \pm 0.4$ & pH $5.1 \pm 0.2$ & $\mathrm{pH} 4.1 \pm 0.3$ \\
\hline \multirow{4}{*}{ C. albicans 1486} & $100.0 \mathrm{mcg}$ & $21.8 \pm 0.08$ & $20.3 \pm 0.08$ & $20.0 \pm 0.05$ & $*$ \\
\hline & $50.0 \mathrm{mcg}$ & $20.2 \pm 0.08$ & $18.7 \pm 0.08$ & $19.3 \pm 0.33$ & $*$ \\
\hline & $25.0 \mathrm{mcg}$ & $18.0 \pm 0.25$ & $16.8 \pm 0.08$ & $17.5 \pm 0.75$ & * \\
\hline & $10.0 \mathrm{mcg}$ & $17.3 \pm 1.33$ & $15.3 \pm 2.33$ & $15.8 \pm 1.08$ & * \\
\hline
\end{tabular}

Note: "-" - the zone of the growth inhibition was not registered; * - the effect was not studied.

nomena were registered for E. coli, and the dependence of the effect on the $\mathrm{pH}$ was the most apparent after addition of decamethoxinum in the amount of $10 \mathrm{mcg}$ (that might be connected with the specificity of the substance penetration into the cell of the gram-negative bacteria). In relation to $P$. aeruginosa the most significant effect was observed at $\mathrm{pH} 8.0 \pm 0.1$, the decrease of the $\mathrm{pH}$ value to $7.15 \pm 0.2$ was accompanied with reduction of the inhibitory effect, while at $\mathrm{pH} 5.1 \pm 0.2$ the zones of the growth inhibition were not registered at all. Somewhat different results were obtained after the experiments with $S$. paratyphi: the antibacterial activity of decamethoxinum increased with the increase of the $\mathrm{pH}$ value, still the sufficient activity was present in the neutral and acidic medium. The antifungal effect of decamethoxinum did not change significantly with the $\mathrm{pH}$ and, after addition of decamethoxinum in the amount of $10 \mathrm{mcg}$ the zones of the growth inhibition were within the range of $15.3-17.3 \mathrm{~mm}$.

3. The effect of decamethoxinum on the process of biofilm formation

$E$. coli biofilms were not sensitive to the substance action in the concentration of 1.0 MIC, but the increase of concentration up to $10.0 \mathrm{MIC}$ allowed obtaining a significant effect: inhibition of biofilm formation reached $48 \%$ at $\mathrm{pH} 8.0 \pm 0.1 ; 41 \%$ at $\mathrm{pH} 7.15 \pm 0.2 ; 39 \%$ at $\mathrm{pH}$ $6.3 \pm 0.4$. Biofilm formation of $P$. aeruginosa slightly re- duced in the presence of decamethoxinum in the concentration of $1.0 \mathrm{MIC}(1.7 \%$ at $\mathrm{pH} 8.0 \pm 0.1 ; 5.4 \%$ at $\mathrm{pH}$ $6.3 \pm 0.4$; there was no effect at $\mathrm{pH} 7.15 \pm 0.2)$; at higher concentrations the increase in the activity was also registered with inhibition of $54 \%$ at $\mathrm{pH} 8.0 \pm 0.1 ; 39 \%$ at $\mathrm{pH}$ $7.15 \pm 0.2 ; 37 \%$ at $\mathrm{pH} 6.3 \pm 0.4$. Thus, decamethoxinum could inhibit the process of biofilm formation by the gramnegative bacteria.

4. The effect of decamethoxinum on the biomass accumulation of the microorganisms

Decamethoxinum was able to inhibit the growth and reproduction of the cultivated $P$. aeruginosa (Fig. 1). The inhibitory effect was registered in 6 hours of incubation at $\mathrm{pH} 6.3 \pm 0.4$; it reached a significant level in 12 hours in all media and subsequently increased. Therefore, in 48 hours the biomass accumulation of $P$. aeruginos $a$ was blocked at all $\mathrm{pH}$ values studied. The effect of the substance studied on E. coli is shown in Fig. 2. This strain appeared to be sensitive to decamethoxinum with the inhibitory action seen as early as in 1 hour of incubation in the basic medium with the increase in the subsequent hours and the highest activity in 48 hours. Decamethoxinum also inhibited the growth and reproduction of the cultivated $S$. paratyphi B 252 with the effect being dependent on the $\mathrm{pH}$ and the time of incubation (Fig. 3). The most active inhibition of these bacteria in the bio- 


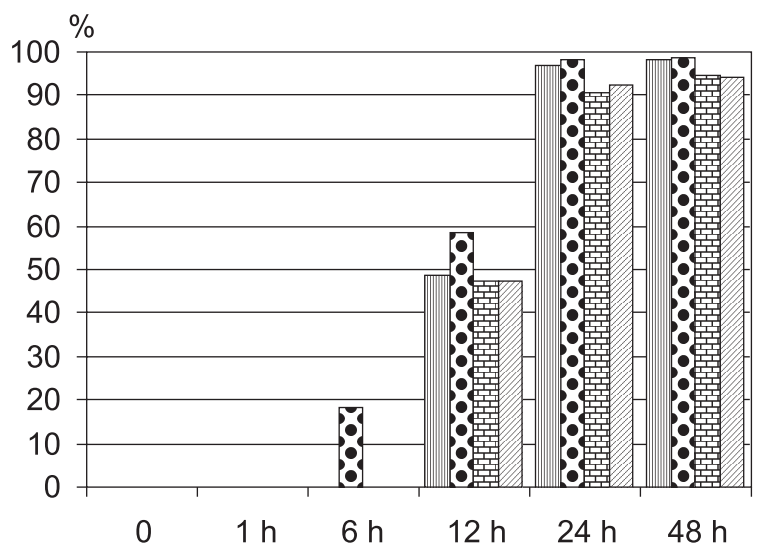

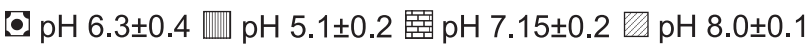

Fig. 1. The effect of decamethoxinum on the biomass accumulation of Pseudomonas aeruginosa 2094 at different $\mathrm{pH}$ values. The data are given as $\%$ of inhibition (the individual control data are taken as $100 \%$ ), decamethoxinum is used in the minimal inhibitory concentration (1.0 MIC).

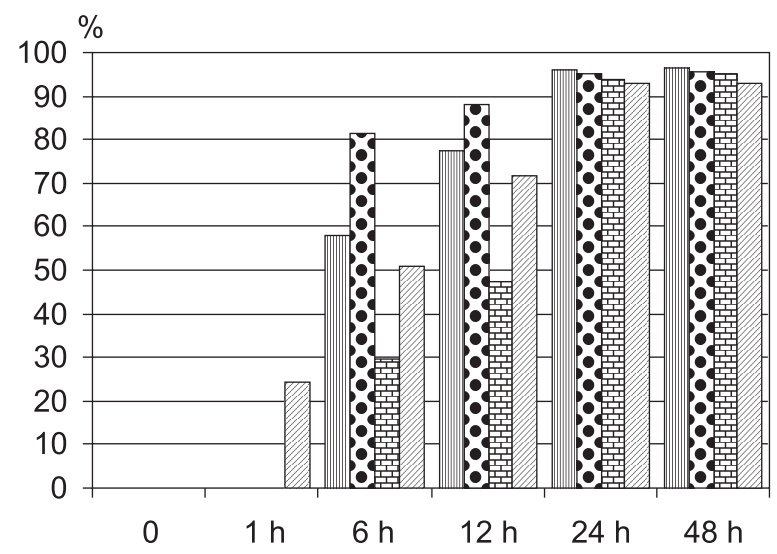

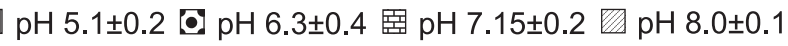

Fig. 2. The effect of decamethoxinum on the biomass accumulation of Escherichia coli 1512 at different $\mathrm{pH}$ values. The data are given as $\%$ of inhibition (the individual control data are taken as $100 \%$ ), decamethoxinum is used in the minimal inhibitory concentration (1.0 MIC).

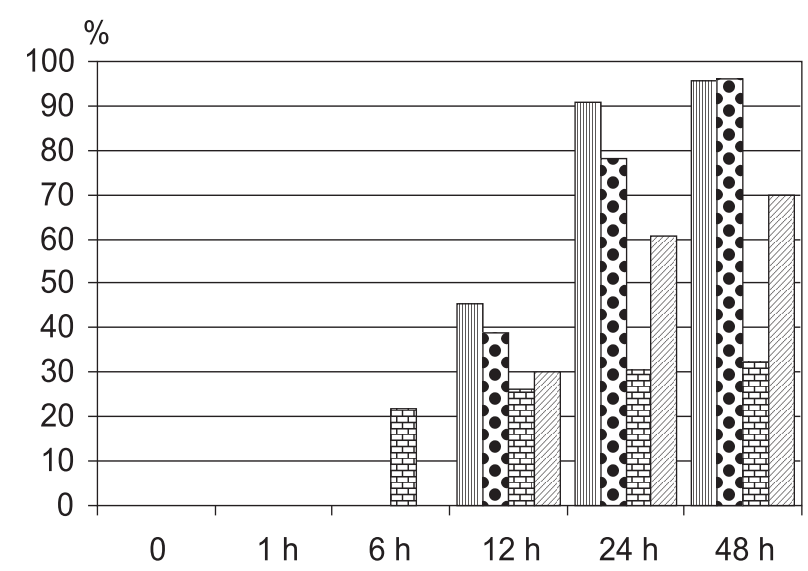

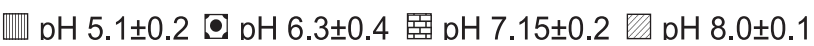

Fig. 3. The effect of decamethoxinum on the biomass accumulation of Salmonella paratyphi B 252 at different $\mathrm{pH}$ values. The data are given as \% of inhibition (the individual control data are taken as $100 \%$ ), decamethoxinum is used in the minimal inhibitory concentration (1.0 MIC)

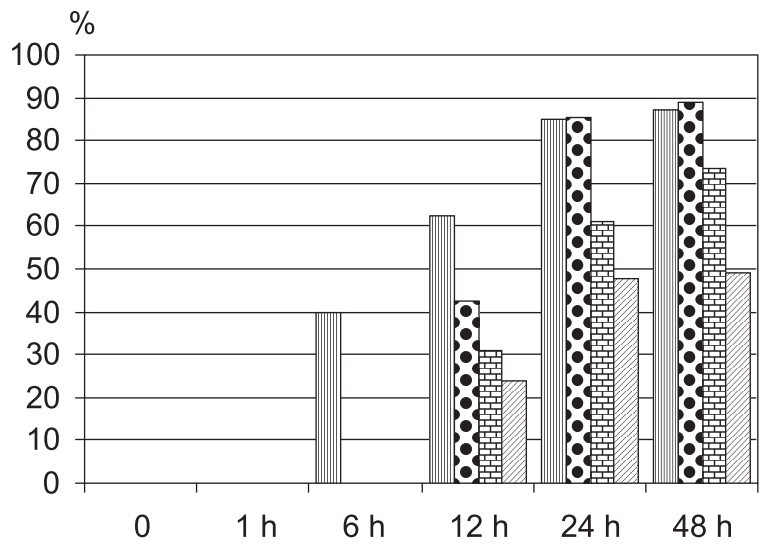

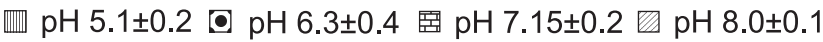

Fig. 4. The effect of decamethoxinum on the biomass accumulation of Staphylococcus aureus 042012 at different $\mathrm{pH}$ values. The data are given as \% of inhibition (the individual control data are taken as $100 \%$ ), decamethoxinum is used in the minimal inhibitory concentration (1.0 MIC).

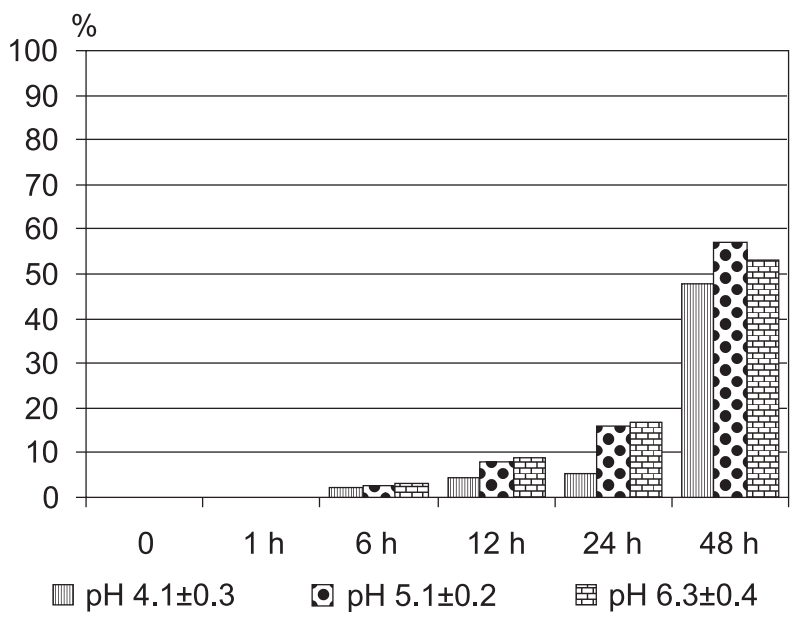

Fig. 5. The effect of decamethoxinum on the biomass accumulation of Candida albicans 1486at different $\mathrm{pH}$ values. The data are given as $\%$ of inhibition (the individual control data are taken as $100 \%$ ), decamethoxinum is used in the minimal inhibitory concentration (1.0 MIC).

mass accumulation in 6 hours was observed at $\mathrm{pH} 7.15 \pm 0.2$, in other periods under study - at $\mathrm{pH} 5.1 \pm 0.2$ and $\mathrm{pH}$ $6.3 \pm 0.4$ (less but still significant effect was also seen at $\mathrm{pH} 8.0 \pm 0.1$ ). In relation to $S$. aureus 042012 the inhibitory activity of decamethoxinum was registered in 6 hours at $\mathrm{pH} 5.1 \pm 0.2$ and subsequently increased in all media, especially at $\mathrm{pH} 5.1 \pm 0.2$ and $\mathrm{pH} 6.3 \pm 0.4$ (Fig. 4). When the bactericidal concentration of 10.0 MIC was used, decamethoxinum exerted a significant antimicrobial effect from the first hours without a dependence on the $\mathrm{pH}$. The antifungal action of the substance studied against C. albicans 1486 began in 6 hours of incubation and reached the values close to inhibition of $50 \%$ in 48 hours in all media. In the concentration of 10.0 MIC decamethoxinum completely blocked the biomass accumulation of C. albicans 1486 at all $\mathrm{pH}$ values studied.

\section{CONCLUSIONS}

1. Decamethoxinum substance exhibits significant antimicrobial properties against $P$. aeruginosa, E. coli, $S$. aureus, $S$. paratyphi, and C. albicans with the depen- 
dence of the inhibitory effect on the microorganism species and $\mathrm{pH}$ of the medium. Determination of MIC values shows that the antimicrobial activity of decamethoxinum against bacteria and fungi increases in the basic medium.

2 . In the agar diffusion assay decamethoxinum substance demonstrates the antimicrobial action in the concentrations of $100.0 ; 50.0 ; 25.0 ; 10.0 \mathrm{mcg} / \mathrm{ml}$. Diameters of the zones of the microorganism growth inhibition depend on the microorganism species and the $\mathrm{pH}$ of the medium: the highest activity against $P$. aeruginosa, $S$. aureus, E. coli is observed at $\mathrm{pH} 8.0 \pm 0.1$, against $C$. albicans - at $\mathrm{pH} 7.15 \pm 0.2$, against $S$. paratyphi - at $\mathrm{pH}$ $8.0 \pm 0.1$ and $\mathrm{pH} 5.1 \pm 0.2$.

3. Decamethoxinum substance inhibits formation of biofilms by $P$. aeruginosa and $E$. coli, this effect also depends on the concentration and $\mathrm{pH}$. The most active inhibition of biofilm formation is achieved in the concentration of $10.0 \mathrm{MIC}$ and $\mathrm{pH} 8.0 \pm 0.1$.
4. In the concentration of 1.0 MIC decamethoxinum substance decreases the biomass accumulation of E. coli (in 1 hour at $\mathrm{pH} 8.0 \pm 0.1$, in the other periods the activity under research is increased in all of the media studied), S. paratyphi (in 24 and 48 hours of incubation in both basic and acidic media), $P$. aeruginosa (in 12 and, especially 24 hours, as well as 48 hours of incubation in all of the media studied), S. aureus (in 1 hour at $\mathrm{pH} 5.1 \pm 0.2$, in 24 and 48 hours at $\mathrm{pH} 5.1 \pm 0.2$, and in 12 hours at $\mathrm{pH} 6.3 \pm 0.4$ with a less significant effect). In the bactericidal/fungicidal concentration of $10.0 \mathrm{MIC}$ decamethoxinum inhibits the biomass accumulation of bacteria/fungi from the first hours without a dependence on $\mathrm{pH}$. The sensitivity of $C$. albicans to the antifungal action of decamethoxinum has not also been determined by $\mathrm{pH}$ in the concentration of $1.0 \mathrm{MIC}$ (the significant activity in this case is registered in 48 hours of incubation).

\section{REFERENCES}

1. Волянський Ю.Л. Вивчення спещифічної активності антимікробних лікарських засобів: Метод. рекоменд. МОЗ України / Ю.Л.Волянський, І.С.Гриценко, В.П.Широбоков та ін. - К.: ДФЦ МОЗ Украйни, 2004. $-38 c$.

2. Декасан: инструкиия по применению [Електронний ресурс]. - Режим достуny: http://tabletki.иа/Декасан

3. Деркач Н.М., Штриголь С.Ю., Лар'яновська Ю.Б. та ін. // Клін. та експерим. патол. - 2016. - Т. ХV, №2(56), Ч. 1. - C. 59-66.

4. Деркач Н.Н., Штрыголь С.Ю., Койро О.О., Блажеевский Н.Е. // Обзоры по клин. фармакол. и лекарств. терапии. - 2015. - T. 15, №1. - C. 45-51.

5. Некрасова Л.С., Свита В.М., Глушкевич Т.Г. та ін. Визначення чутливості мікроорганізмів до антибактеріальних препаратів: МВ 9.9.5-143-2007 / Держ. сан.-епідеміол. служба МОЗ України. - К., 2007. - 79 с.

6. Определение чувствительности микроорганизмов к антибактериальныл препаратам: МУК 4.2.1890-04 // Клин. микробиол. антимикроб. химиотерапия. - 2004. - Т. 6, №4. - С. 306-359.

7. Палій Г.К., Ковальчук В.П., Деркач Н.М. та ін. // Укр. хіміотерапевт. журн. - 2010. - №1-2.- С. 78-82.

8. Пат. UА 103366 на корисну модель МПК (2015.01) А 61 К31/00 А 61 P 1/00 / Н.М.Деркач, С.Ю.Штриголь, Н.І.Філімонова та ін. - № и2015 06523. - Заявл.: 02.07.2015. Опубл.: 10.12.2015. - Бюл. №23. - 6 с.

9. Практическое руководство по антиинфекиионной химиотерапии / Под ред. Л.С.Страчунского, Ю.Б.Белоусова, С.Н.Козлова. - М.: Боргес, 2002. - 381 c.

10. Романова Ю.М., Смирнова Т.А., Андреев А.Л. и др. // Микробиол. - 2006. - №4. - С. 556-561.

11. Современные методы клинической микробиологии / Под ред. Л.С.Страчунского, Р.С.Козлова. - Смоленск: МАКМАХ, 2003. - 104 c.

12. Barr W., Smith A. // Am. Fam. Physician. - 2014. - Vol. 89, №3. - P. 180-189.

13. Wolcott R.D., Ehrlich G.D. // JAMA. - 2008. - Vol. 299, №22. - P. 2682-2684.

\section{АНТИМІКРОБНА АКТИВНІСТЬ СУБСТАНЦІЇ ДЕКАМЕТОКСИНУ ЗА РІЗНИХ ЗНАЧЕНЬ Н.М.Деркач, 3.С.Суворова}

Ключові слова: декаметоксин; «Декасан»; антимікробна дія; протигрибкова дія; $\mathrm{pH}$ Роботу присвячено визначенню впливу рН на специфрічну активність субстанції декаметоксину в експерименті. Показано, що мінімальна інгібуюча концентрація (МІК) даної субстанції залежить від виду мікроорганізму та рН із найнижчими значеннями МIК для S. aureus, P. aeruginosa, E. coli в лужному середовищі. Значну антимікробну активність відносно S. paratyphi верифріковано як у кислому, так і в лужному середовищі, тимчасом як протигрибковий ефект відносно C. albicans зростає в лужному середовищі. Встановлено, що декаметоксин пригнічує процес плівкоутворення E. coli ma P. aeruginosa, eфpeкт є залежним

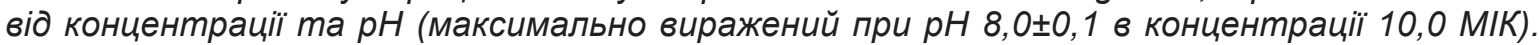
Декаметоксин інгібує накопичення біомаси мікроорганізмів, що також залежить від $\mathrm{pH}$. Так, стримування росту та розмноження $P$. aeruginosa виявляється через 6 год інкубації з суб-

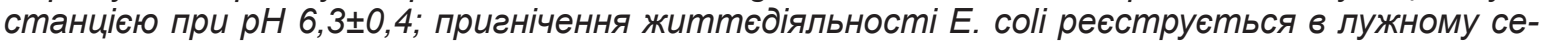




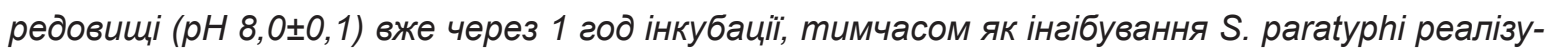

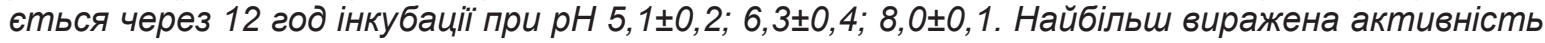
декаметоксину відносно грампозитивних бактерій (S. aureus) виявляється через 6 год інкубації при рН 5,1士0,2. У зазначеному кислому середовищі також встановлено протигрибкову активність декаметоксину відносно C. albicans із інгібуванням накопичення клітин через 12 год після внесення субстанції.

\section{ПРОТИВОМИКРОБНАЯ АКТИВНОСТЬ СУБСТАНЦИИ ДЕКАМЕТОКСИНА ПРИ РАЗЛИЧНЫХ} ЗНАЧЕНИЯХ $\mathrm{PH}$

\section{Н.Н.Деркач, З.С.Суворова}

Ключевые слова: декаметоксин; «Декасан»; антимикробное действие; противогрибковое действие; $\mathrm{pH}$

Работа посвящена определению влияния рН на специфическую активность субстанции декаметоксина в эксперименте. Показано, что минимальная ингибирующая концентрация (МИК) данной субстанции зависит от вида микроорганизма и $\mathrm{pH}$, наименьшие значения МИК для S. aureus, P. aeruginosa, E. coli определяются в щелочной среде. Значительная антимикробная активность относительно S. paratyphi верифрицирована как в кислой, так и в щелочной среде, тогда как противогрибковый эфффект относительно C. albicans возрастает в щелочной среде. Установлено, что декаметоксин подавляет прочесс пленкообразования E. coli u P. aeruginosa, эфффект зависит от концентрации и pH (максимально выражен при рН

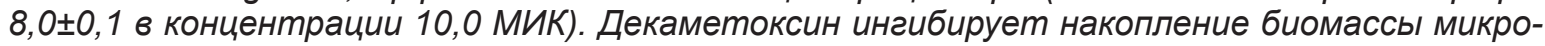
организмов, что также зависит от $\mathrm{pH}$. Так, подавление роста и размножения $P$. aeruginosa

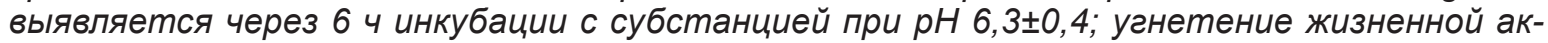
тивности E. coli регистрируется в щелочной среде $(\mathrm{pH} \mathrm{8,0 \pm 0,1)} \mathrm{уже} \mathrm{через} 1$ ч инкубации,

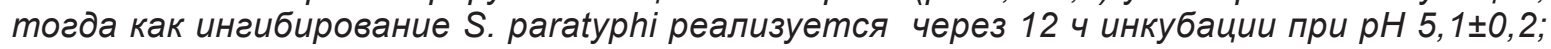
$6,3 \pm 0,4 ; 8,0 \pm 0,1$. Наиболее выраженная активность декаметоксина относительно граммпо-

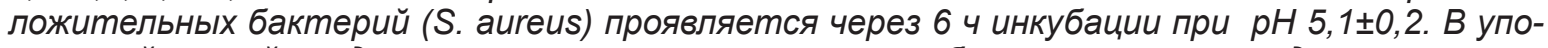
мянутой кислой среде также установлена противогрибковая активность декаметоксина относительно C. albicans c ингибированием накопления клеток через 12 ч после внесения субстанции. 